\title{
The genetic relationships and Indo-Pacific connectivity of whale sharks (Rhincodon typus) with particular reference to mitochondrial COI gene sequences from Cendrawasih Bay, Papua, Indonesia
}

\author{
ABDUL HAMID A. TOHA ${ }^{1, \vartheta}$, MUHAMMAD DAILAMI ${ }^{2}$, SAIFUL ANWAR ${ }^{3}$, JUSWONO B. SETIAWAN ${ }^{4}$, \\ YUSUP JENTEWO ${ }^{4}$, IDA LAPADI ${ }^{1}$, SANNY SUTANTO ${ }^{3}$, RATIH ARYASARI ${ }^{5}$, AMBARIYANTO ${ }^{6}$, \\ FERAWATI RUNTUBOI ${ }^{7}$, HAWIS MADDUPPA ${ }^{8}$ \\ ${ }^{1}$ Department of Fisheries, Faculty of Fisheries and Marine Science, Universitas Papua. Jl. Gunung Salju, Manokwari 98314, West Papua, Indonesia. \\ Tel./fax. +62-813-81903136, `email: h.toha@unipa.ac.id. \\ ${ }^{2}$ Department of Aquaculture, Faculty of Fisheries and Marine Science, Universitas Brawijaya. Jl. Veteran No. 16, Malang 65145, East Java, Indonesia \\ ${ }^{3}$ Teluk Cenderawasih National Park Office. J1. Dr. Esau Sesa, Sowi Gunung, Manokwari 98315, West Papua, Indonesia \\ ${ }^{4}$ World Wildlife Fund-Indonesia region of Cenderawasih Bay. Rado, Wasior, Teluk Wondama 98362, West Papua, Indonesia \\ ${ }^{5}$ Program of Biology, Faculty of Biology, Universitas Gadjah Mada. Jl. Teknika Selatan, Sekip Utara, Sleman 55281, Yogyakarta, Indonesia \\ ${ }^{6}$ Department of Marine Science, Faculty of Fisheries and Marine Science, Universitas Diponegoro. J1. Prof. H. Soedarto, Tembalang, Semarang 50275, \\ Central Java, Indonesia \\ ${ }^{7}$ Department of Marine Science, Faculty of Fisheries and Marine Science, Universitas Papua. J1. Gunung Salju, Manokwari 98314, West Papua, Indonesia \\ ${ }^{8}$ Department of Marine Science and Technology, Faculty of Fisheries and Marine Science, Institut Pertanian Bogor. Jl. Agatis, Dramaga, Bogor 16680, \\ West Java, Indonesia
}

Manuscript received: 21 January 2020. Revision accepted: 23April 2020.

\begin{abstract}
Toha AHA, Dailami M, Anwar S, Setiawan JB, Jentewo Y, Lapadi I, Sutanto S, Aryasari R, Ambariyanto, Runtuboi D, Madduppa H. 2020. The genetic relationships and Indo-Pacific connectivity of whale sharks (Rhincodon typus) with particular reference to mitochondrial COI gene sequences from Cendrawasih Bay, Papua, Indonesia. Biodiversitas 21: 2159-2171. Cenderawasih Bay, in the Birdhead Seascape of Papua, is a favorable habitat for whale sharks (Rhincodon typus). They are frequently sited in this large open Bay but little is known about their genetic characteristics and their connection to whale shark populations in other parts of the world. The study reported in this paper was conducted to characterize the nucleotide sequences of the COI gene fragment in whale sharks from Cenderawasih Bay, and to compare these with sequences held in GeneBank for the COI gene fragment obtained from 27 whale sharks sampled around the Indian and Pacific Oceans. A total of 28 meat samples of whale shark in the Bay were collected by a biopsy punch attached to a pole spear. The DNA of the meat samples was extracted to obtain whole genomes which were then amplified and sequenced to identify nucleotides of the COI gene fragments of the mitochondrial DNA. The size determined for the COI gene fragment from all Cenderawasih Bay samples was $669 \mathrm{bp}$, consisting of $\mathrm{A}=26.5 \%, \mathrm{~T} / \mathrm{U}=30.5 \%, \mathrm{C}=28.3 \%$, dan $\mathrm{G}=14.7 \%$. In total, there were 41 cutting sites obtained for each of the 28 sequences, ranging in length from 5 to $7 \mathrm{bp}$. One COI single nucleotide polymorphism and two haplotypes were identified within the Cenderawasih Bay population. A single site substitution change from $\mathrm{T}$ to $\mathrm{C}$ was observed for both haplotypes. Overall, the haplotype diversity $(\mathrm{Hd}=0.137)$ and nucleotide diversity $(\pi=0.0002)$ were relatively low. Differences were detected in the nucleotide composition, number and arrangement in the COI sequences obtained from Cenderawasih Bay compared with the other Indo_Pacific COI gene fragment sequences deposited in GenBank. This study makes a contribution to our understanding of the molecular systematics, phylogeography, genetic differentiation and conservation genetics of the whale shark (R. typus).
\end{abstract}

Keywords: Cenderawasih Bay, GenBank, haplotype, Papua, nucleotide

\section{INTRODUCTION}

Cenderawasih Bay is one of the hotspots for the sighting of whale sharks (Rhincodon typus) in Indonesia (Stewart 2011; Tania 2015; Suruan 2017). They are very frequently observed in this area (Stewart 2011; HoegGuldberg et al. 2009; Tania 2015; Suruan 2017). During monitoring of whale sharks in Cenderwasih Bay, 126 sightings were recorded in the period February 2010 to April 2015 (Tania 2015) and 150 sightings in 2018 (Bawole et al. 2018). The average size of sighted whale sharks in Cenderawasih Bay is $4.4 \pm 1.25 \mathrm{~m}$ (Tania 2015; Bawole et al. 2018; Toha et al. 2019). Immature and mostly male whale sharks are frequently observed in
Cenderawasih Bay (Tania et al. 2013; Tania 2014a; Tania 2014b; Bawole et al. 2018; Toha et al. 2019).

Researchers investigating the global distribution of whale sharks have identified the cytochrome $c$ oxidase subunit I, COI, gene fragment, in the mitochondrial DNA (mtDNA) as a particularly suitable marker for interspecific population genetic studies (Ward et al. 2005; Kerr et al. 2009; Wong et al. 2009; Alam et al. 2014; Saleky et al. 2016). Coding genes of the mtDNA, including the COI gene, are also usually used for phylogenetic studies (DeBoer et al. 2014a; Pranata et al. 2018a, 2018b). This gene has a rapid rate of mutation, which allows the discrimination of closely associated species (Hebert et al. 2003b) and phylogeographic groups within a single species 
(Wares and Cunningham 2001; DeBoer et al. 2014b). It is often used as a DNA barcode to identify animal species (Toha et al. 2015; Dailami et al. 2018) and other species (see Carpenter et al. 2011).

Whale sharks have been a challenging subject for research not only in Cenderawasih Bay but also in other regions of the world (Rezzolla and Storai 2010). Research on whale sharks in Cenderawasih Bay has covered many aspects of their biology and ecological status (Tania and Noor 2014; Tania 2015; Anna 2016; Kunarso 2016; Marliana 2016; Prihadi 2016; Suruan 2017; Bawole et al. 2018; Widiastuti et al. 2018), including genetic aspects (Toha et al. 2014, 2016). Although there has been an increase in global research over the past ten years, there has been little research on the genetic characteristics of whale sharks in the Cenderawasih Bay region. Yet, such research is important if we wish to gain a full understanding of the genetic diversity of this fascinating but vulnerable marine species (Fowler 2000; Pravin 2000; CITES 2002; Theberge and Dearden 2006; Pierce and Norman 2016). Unfortunately, except for Toha et al. (2016) who used the COI gene to analyze the genetic relationship of whale sharks, most genetic researchers of whale sharks have focused their attention on the control region (or mtDNA displacement loop) as a molecular marker, especially for population genetic studies (Castro et al. 2007; RamírezMacías et al. 2007; Ahonen et al. 2009). Research using COI gene markers for whale sharks is limited. Until recently, genetic research on whale sharks using the COI gene markers amounted to only 27 sequences recorded in GenBank (https: //www.ncbi.nlm.nih.gov). For this reason, our study aimed to determine the characteristics of the COI
mtDNA gene among whale sharks of Cendrawasih Bay waters and to compare these with the 27 available sequences deposited in GenBank.

\section{MATERIALS AND METHODS}

\section{Sampling and data collection}

A total of 28 samples from Cenderwasih Bay whale sharks were processed in this study (Figure 1, Table 1). These comprised 18 newly collected tissue samples (with sample IDs: WS), together with 10 sequences from old samples (with sample IDs: HP) that had been collected from Cenderawasih Bay waters in a previous study (Toha et al. 2016). All skin tissue samples were collected with modified hog ear notch pliers and small biopsy tips, and all necessary national and local permits to do this were obtained. The samples were preserved in $96 \%$ ethanol and stored at $4{ }^{\circ} \mathrm{C}$ in the laboratory until DNA isolation. A photo ID of each whale shark was used at the time of tissue sampling (Azourmanian et al. 2005) so that there was no repeat sampling of the same individual. In total, the data from 28 samples (with sample IDs: WS, whale shark, and $\mathrm{HP}$, hiu paus=whale shark in Bahasa) were analyzed in this study. We also assembled the data from the 27 nucleotide sequences of whale shark from previous studies deposited in GenBank (https: //www.ncbi.nlm.nih.gov). The 27 GenBank gene sequences for the COI mtDNA data for whale sharks (Rhincodon typus) were compiled from: https: //www.ncbi.nlm.nih.gov/nuccore/?term=coi+gene+of+Rhin codon+typus+.

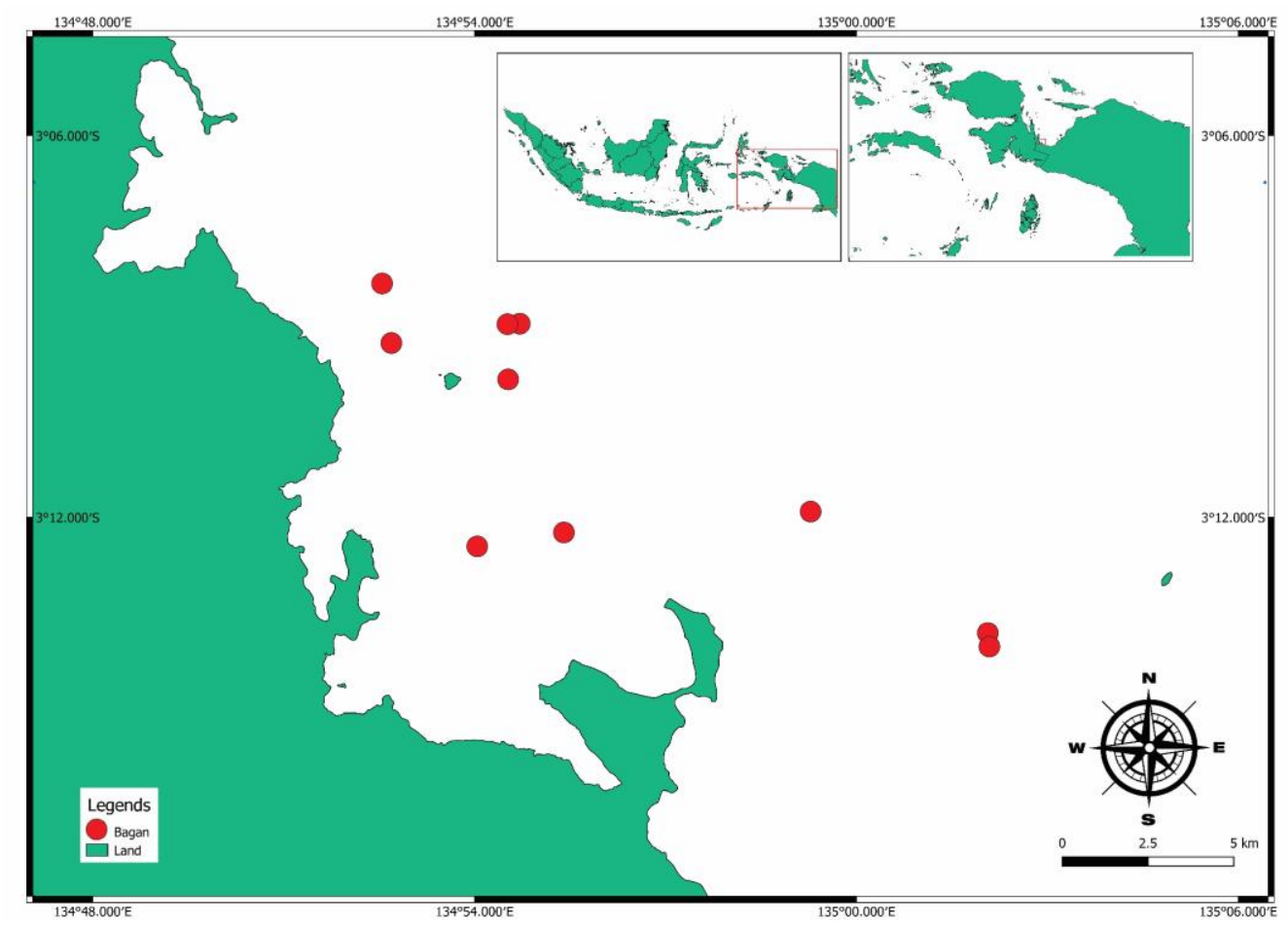

Figure 1. Research Locations in Cenderawasih Bay, West Papua, Indonesia. Sampling locations are shown as red circles. 
Table 1. ID for 18 new whale shark samples from Cenderawasih Bay, with sampling locations (bagan names) and their

\begin{tabular}{llll}
\hline Sample ID no. & Bagan *names & Latitude (S) & Longitude (E) \\
\hline WS ID 137 & Cahaya Nurul & $03^{\circ} 12.472^{\prime}$ & $134^{\circ} 54.044^{\prime}$ \\
WS ID 078 & Cahaya Nurul & $03^{\circ} 12.472^{\prime}$ & $134^{\circ} 54.044^{\prime}$ \\
WS ID 138 & Cahaya Nur Tasya & $03^{\circ} 12.252^{\prime}$ & $134^{\circ} 55.416^{\prime}$ \\
WS ID 122 & Cahaya Nur Tasya & $03^{\circ} 12.252^{\prime}$ & $134^{\circ} 55.416^{\prime}$ \\
WS ID 069 & Cahaya Pinrang & $03^{\circ} 14.031^{\prime}$ & $135^{\circ} 02.096^{\prime}$ \\
WS ID 140 & Cahaya Pinrang & $03^{\circ} 14.031^{\prime}$ & $135^{\circ} 02.096^{\prime}$ \\
WS ID 141 & Cahaya Pinrang & $03^{\circ} 13.895^{\prime}$ & $135^{\circ} 02.076^{\prime}$ \\
WS ID 047 & Cahaya Pinrang & $03^{\circ} 13.895^{\prime}$ & $135^{\circ} 02.076^{\prime}$ \\
WS ID 132 & Cahaya Madina & $03^{\circ} 09.000^{\prime}$ & $134^{\circ} 54.635^{\prime}$ \\
WS ID 016 & Buah Padi & $03^{\circ} 08^{\prime} 20.4^{\prime \prime}$ & $134^{\circ} 52^{\prime} 33.1^{\prime \prime}$ \\
WS ID 043 & Buah Padi & $134^{\circ} 52^{\prime} 33.1^{\prime \prime}$ \\
WS ID 144 & Cari Nafkah Indah & $3^{\circ} 09^{\prime} 16.5^{\prime \prime}$ & $134^{\circ} 52^{\prime} 41.9^{\prime \prime}$ \\
WS ID 145 & $3^{\circ} 09^{\prime} 01.2^{\prime \prime}$ & $134^{\circ} 54^{\prime} 31.9^{\prime \prime}$ \\
WS ID 146 & Cahaya Madina & $3^{\circ} 09^{\prime} 01.2^{\prime \prime}$ & $134^{\circ} 54^{\prime} 31.9^{\prime \prime}$ \\
WS ID 147 & $3^{\circ} 09^{\prime} 50.5^{\prime \prime}$ & $134^{\circ} 54^{\prime} 31.7^{\prime \prime}$ \\
WS ID 148 & Cahaya Madina & $3^{\circ} 09^{\prime} 50.5^{\prime \prime}$ & $134^{\circ} 54^{\prime} 31.7^{\prime \prime}$ \\
WS ID 149 & Buah Padi & $3^{\circ} 09^{\prime} 50.5^{\prime \prime}$ & $134^{\circ} 54^{\prime} 31.7^{\prime \prime}$ \\
WS ID 150 & Buah Padi & $3^{\circ} 11^{\prime} 55.2^{\prime \prime}$ & $134^{\circ} 59^{\prime} 17.6^{\prime \prime}$ \\
\hline
\end{tabular}

Note: * Bagan is a traditional set of fish traps made of light-mounted nets.

\section{Isolation, PCR, and sequencing}

The total genome of each whale shark meat sample was isolated using a Genomic DNA mini kit, supplied by Geneaid $_{\circledast}$. The manufacturer's standard protocol was followed, and the resultant isolated genomic DNA was then amplified using the primer pair FISH-BCL: 5 'TCAACYAATCAYAAAGATATYGGCAC-3' and FISHBCH: 5'-TAAACTTCAGGGTGACCAAAAAATCA-3 ' (Baldwin et al. 2008). The master mix used for PCR was the "Go Taq Green PCR-Mix" product from Promega ${ }_{\circledast}$. PCR was carried out using the master mix with a total reagent volume of $50 \mu \mathrm{L}$ per reaction. The $50 \mu \mathrm{L}$ of reagent consisted of $17 \mu \mathrm{L}$ dd $\mathrm{H}_{2} \mathrm{O}$ (sterile, ultra-pure water), $2.5 \mu \mathrm{M}$ FISH-BCL, $2.5 \mu \mathrm{L}$ FISH-BCH $(10 \mu \mathrm{M}), 1$ $\mu \mathrm{L}$ DMSO, $25 \mu \mathrm{L}$ Go Taq Green PCR Mix, and $2 \mu \mathrm{L}$ template DNA. The PCR conditions were set as follows: the machine was heated at $80^{\circ} \mathrm{C}$ for 10 seconds, followed by pre-denaturation at $94^{\circ} \mathrm{C}$ for 3 minutes, 40 cycles of denaturation at $94^{\circ} \mathrm{C}$ for 30 seconds, annealing at $50^{\circ} \mathrm{C}$ for 30 seconds and extension at $72^{\circ} \mathrm{C}$ for 45 seconds. The final extension was at $72^{\circ} \mathrm{C}$ for 5 minutes, followed by cooling down at $37^{\circ} \mathrm{C}$. The quality of the PCR products was proven by electrophoresis using $1 \%$ gel agarose in sodium borate buffer ( $\mathrm{pH}$ 8.5). The DNA was stained by ethidium bromide and visualized using a UV transilluminator, then documented by a digital camera (Canon G15 series). The positive PCR products were sequenced by PT. Genetika Science Indonesia using the Sanger (dideoxy) method.

\section{Data analysis}

DNA barcodes for identification of whale shark species were determined by BLAST (Basic Local Alignment Search Tools). Bardcode DNA can also be constructed by the BOLD System (Barcode of life data system v4) method. Both methods of analysis use an approach that assesses homology between sequences obtained from the research samples with sequences of genetic data deposited in GenBank and BOLD System. The results of these two approaches are tabulated to show the identity corresponding to the research sample. Sequence source, length, and number for each sample was assessed online in GenBank using the deposited nucleotide sequences for the COI gene of Rhincodon typus, accessed at https: //www.ncbi.nlm.nih.gov/nuccore/?term=coi+gene+of+Rhin codon+typus+.

\section{Genetic characteristics}

Genetic characteristics related to nucleotide composition, GC and AT ratios, R values, and mutations were analyzed using MEGA6. MEGA6 was also used to predict the net evolutionary differences between the population of Cenderawasih Bay whale sharks and other populations. The sequence diversity was assessed based on homogeneity tests and disparity index substitution patterns between sequences, using MEGA6 (Tamura et al. 2013). Sequence diversity was also analyzed to detect presence of polymorphic sites, number of haplotypes, nucleotide diversity, and diversity of haplotypes, using the DnaSP program (Librado and Rozas 2009). Cutting edges (restriction endonuclease cleavage sites) for sequences from the COI gene fragments were analyzed online at http: //www.restrictionmapper.org.

\section{Genetic connectivity}

Analysis of molecular variance (AMOVA) among sample sequences was calculated through 1000 permutations. The statistical calculations were carried out using the software package Arlequin version 3.5 (Excoffier and Lischer 2010). Phylogenetic trees to reconstruct relationships between individual whale sharks and between populations were carried out based on the neighbor-joining method using MEGA6. Genetic distance measurements between individuals in the phylogenetic tree were also determined using MEGA6 (Tamura et al. 2013). 


\section{RESULTS AND DISCUSSION}

All the COI mtDNA sequence data for the whale sharks obtained in this study have been deposited in GenBank. The GenBank provided accession numbers for our 28 nucleotide sequences, from MN759737 to MN759764.

BLAST results for COI gene fragment sequences revealed strong similarity between individuals of the Cenderawasih Bay whale shark population, and supported the inference that all 28 individuals were from one species, Rhincodon typus. The BOLD System analysis showed the same results. All samples of Cenderawasih Bay whale sharks showed very high similarity (between 99-100\%) with $R$. typus. This result is in accordance with expert opinion that whale sharks belong to only one species, $R$. typus.

\section{Genetic characteristics}

In GenBank, we were able to obtain only 27 whale shark COI sequences from other countries. The number of sequences (28) that we have obtained from Cenderawasih Bay exceeds the number (27) deposited in GenBank from other geographical locations. Table 2 presents a summary list of these sequences based on the country or region of the sourced samples.

Overall, there are 55 COI gene fragment sequences, including the ones from Cenderawasih Bay. The whale shark in sequences from Cenderawasih Bay amount to $50.9 \%$ of all existing sequences to date. All sequences of the COI gene fragments determined from Cenderawasih Bay whale sarks had a length of 669 base pairs (bp). Tracking the whale shark COI mtDNA COI data in the GenBank revealed that the recorded sequence lengths ranged from 514 to $705 \mathrm{bp}$ (Table 3 ).

A summary of the nucleotide composition and mutations characteristics for whale shark sequences from various locations including Cenderawasih Bay is presented in Table 4.

The COI gene fragment sequences from Cenderawasih Bay had a transition/transversion (R) bias of 1180325.49. The nucleotide frequency was A (adenine base) $=26.5 \%, \mathrm{~T}$ $/ \mathrm{U}$ (thymine or uracil base $)=30.5 \%, \mathrm{C}$ (cytosine base $)=$ $28.3 \%$, and $\mathrm{G}$ (guanine base) $=14.7 \%$. The nucleotide sequences for the COI gene fragments were identified using 29 restriction enzymes that differ in sequence, side length, type of cut, frequency and cutting side (Table 5).

We identified 41 cutting sites in each sequence of the whale shark COI gene fragment. Cutting site lengths varied between 5 and 7 nucleotides. More than 29 restriction enzymes were identified that cut the sequence whale shark COI gene fragment. Of the 29 restriction enzymes, 19 (PsiI, ScaI, SspI, ApaLI, ApoI, BbvI, BclI, BseYI, EcoP15I, EcoRII, FauI, HindIII, SfaNI, SpeI, TatI, TseI, VspI, BSEMII, PstI) resulted in single cuts to the COI gene fragment sequence while 10 enzymes (XhoII, AloI, BsaXI, BseSI, BsrI, Hin41, MboII, SduI, TaqII, TspDTI) resulted in two or four cut positions. This study identified a polymorphism in the COI sequence among the Cenderawasih whale sharks at nucleotide position No. 284. The polymorphism occurs because of a substitution mutation from $\mathrm{T}$ to $\mathrm{C}$ (Table 6).
This mutation is classified as a transition mutation because it arose from a change from one pyrimidine base to another pyrimidine base. Whale sharks from Cenderawasih Bay exhibit very little diversity in the COI nucleotide sequence. This study identified only two haplotypes in the COI gene fragments amongst the 28 whale shark samples. The first haplotype with a $\mathrm{T}$ (thymine) base at nucleotide 284 was found in 26 individuals, while the second haplotype with a $\mathrm{C}$ (cytosine base) was found in only two individual whale sharks. This is summarised in the statistical analysis which showed the segregation number $(\mathrm{S})=1$, diversity of haplotype $(\mathrm{Hd})=0.137$, average number of differences between sequences $(\mathrm{K})=0.1376$, and nucleotide diversity $(\mathrm{Pi})=0.00025$. The analysis of the 27 COI gene sequences derived from the GenBank also revealed low genetic diversity in the global whale shark population (Table 7).

All sequences have been translated into amino acid sequences, and no stop codons have been found because the COI gene functions is a structural gene that encodes for the cytochrome oxidase I protein. In this study, the COI gene fragment was translated and produced 222 amino acids derived from 19 amino acid types (Figure 2).

The only amino acid not coded for by this COI gene fragment is cysteine (Cys). All samples had similar amino acid composition.

\section{Genetic connectivity}

The results of the AMOVA analysis showed that there was negligible difference in genetic variation among sequences of whale sharks within Cenderawasih Bay, and between sequences of whale sharks in Cenderawasih Bay and in the wider Indian and Pacific oceans. The homogeneity of the substitution pattern between the COI gene fragment sequences showed that all individuals are reflective of a similar evolutionary history. This was indicated by the negligible differences in basic composition bias between sample sequences, with a P-value less than 0.05 significance (Table 8 ).

There are no base differences per site from estimation of net average between populations of all sequences including with Cenderawasih Bay. A much higher value was found only between Pakistan and others.

The phylogenetic tree showed that all the COI gene samples were clustered in two groups with negligible distance between clusters and between individuals within clusters. The combined phylogenetic analysis of COI gene sequences of all individual whale sharks from Cenderawasih Bay and from other parts of the Indo-Pacific represented in GenBank is presented in Figure 3.

Haplotype network indicates that the whale shark is poorly divergent, and suggests that $\mathrm{H} 2, \mathrm{H} 3$, and $\mathrm{H} 4$ are derived from the $\mathrm{H} 1$ haplotype through a single mutation. $\mathrm{H} 1$ was closer to the $\mathrm{H} 4$, than $\mathrm{H} 2$ and $\mathrm{H} 3$.

Across the 55 sequences in the combined data there was no distinctive structure identified among individuals in the phylogenetic tree. The genetic distance between individuals was very close (0.00-0.002). 
Table 2. Sources of the whale shark COI nucleotide sequences deposited in GenBank.

\begin{tabular}{lcll}
\hline Location & $\begin{array}{c}\text { No. } \\
\text { sequence }\end{array}$ & Access code & References \\
\hline Taiwan & 6 & NC_023455.1, FJ519250.1, FJ519251.1, & Alam et al. (2014), Wong et al. (2009), \\
& & FJ519252.1, KF679782.1, EU398993.1 & Ward et al. (2008) \\
Seychelles & 1 & FJ519244.1 Fong et al. (2009) \\
India & 5 & FJ456922.1, FJ375725.1, KF899632.1, & Gopalakrishnan et al. (2008), Rakhee et al. \\
& & KF899633.1, KF899634.1 & (2008), Bineesh et al. (2013) \\
Pakistan & 1 & KP410325.1 & Kanwal et al. (2015) \\
Philippines & 1 & GU440502.1 & Hastings and Burton (2010) \\
South Africa & 4 & FJ519247.1, HQ945887.1, HQ945888.1, & Wong et al. (2009), Steinke et al. (2016) \\
& & HQ945889.1 & \\
Australia & 2 & FJ519248.1, FJ519249.1 & Wong et al. (2009) \\
Mozambique & 3 & MF872726., FJ519245.1, FJ519246.1 & Meekan et al. (2018), Wong et al. (2009) \\
China & 1 & KC633221.1 & Chen et al. (2014) \\
United Arab Emirates & 1 & KM973184.1 & Jabado et al. (2014) \\
Bangladesh & 1 & MH842010.1 & Das and Haque (2018) \\
Peru & 1 & MH194467.1 & Marin et al. (2018) \\
Cenderawasih Bay, Indonesia & 28 & MN759737-MN759764 & This study \\
Total & 55 & & \\
& & & \\
\hline
\end{tabular}

Table 3. Summary of COI nucleotide sequences deposited in GenBank; listing sequence length (bp), number of sequences, access codes and reference citations

\begin{tabular}{lcll}
\hline $\begin{array}{c}\text { Sequence } \\
\text { length (bp) }\end{array}$ & $\begin{array}{c}\text { No. } \\
\text { sequence }\end{array}$ & \multicolumn{1}{c}{ Access code } & \multicolumn{1}{c}{ References } \\
\hline 668 & 3 & KF899633.1, KF899632.1, KF899634 & Bineesh et al. (2013) \\
652 & 13 & EU398993.1, FJ519244.1, FJ519245.1, FJ519246.1, & Ward et al. (2008), Wong et al. (2009), \\
& & FJ519247.1, FJ519248.1, FJ519249.1, FJ519250.1, & Hastings and Burton (2010), Steinke et al. \\
& & FJ519251.1, GU440502.1, HQ945887.1, HQ945888.1, & (2016) \\
705 & 1 & HQ945889.1 & Kanwal et al. (2015) \\
633 & 1 & FJ519252.1 & Wong et al. (2009) \\
584 & 1 & FJ456922.1 & Gopalakrishnan et al. (2008) \\
560 & 1 & FJ375725.1 & Rakhee et al. (2008) \\
514 & 1 & KM973184.1 & Jabado et al. (2014) \\
600 & 1 & MH842010.1 & Das and Haque (2018) \\
674 & 1 & MH194467.1 & Marin et al. (2018) \\
\hline
\end{tabular}

Table 4. Characteristic of whale shark sequences per location

\begin{tabular}{lccccccccl}
\hline \multicolumn{1}{c}{$\begin{array}{c}\text { Characteristic/ } \\
\text { location }\end{array}$} & $\begin{array}{c}\text { Sample } \\
\text { number }\end{array}$ & $\boldsymbol{\%} \mathbf{C}$ & $\boldsymbol{\%} \mathbf{T}$ & $\boldsymbol{\%} \mathbf{A}$ & $\mathbf{\%} \mathbf{G}$ & $\mathbf{T r}$ & $\mathbf{T v}$ & Ps & Source sequences \\
\hline Cenderawasih Bay & 28 & 28.3 & 30.5 & 26.5 & 14.7 & 1 & 0 & 1 & This study \\
Taiwan & 4 & 28.3 & 30.5 & 26.5 & 14.7 & 0 & 0 & 0 & Wong et al. (2009), Ward et al. (2008) \\
Seychelles & 1 & 28.3 & 30.5 & 26.5 & 14.7 & 0 & 0 & 0 & Wong et al. (2009) \\
India & 5 & 28.6 & 30.1 & 26.5 & 14.7 & 5 & 1 & 6 & $\begin{array}{l}\text { Gopalakrishnan et al. (2008), Rakhee et al. } \\
\text { (2008), Bineesh et al. (2013) }\end{array}$ \\
Pakistan & 1 & 15.4 & 26.8 & 29.8 & 27.9 & 0 & 0 & 0 & Kanwal et al. (2015) \\
Philippines & 1 & 28.3 & 30.5 & 26.5 & 14.7 & 0 & 0 & 0 & Hastings and Burton (2010) \\
South Africa & 4 & 28.3 & 30.5 & 26.5 & 14.7 & 0 & 0 & 0 & Wong et al. (2009), Steinke et al. (2016) \\
Australia & 2 & 28.3 & 30.5 & 26.5 & 14.7 & 0 & 0 & 0 & Wong et al. (2009) \\
Mozambique & 2 & 28.3 & 30.5 & 26.5 & 14.7 & 0 & 0 & 0 & Wong et al. (2009) \\
UAE & 1 & 22.8 & 32.5 & 30.0 & 14.8 & 0 & 0 & 0 & Jabado et al. (2014) \\
Bangladesh & 1 & 22.3 & 32.7 & 29.3 & 15.7 & 0 & 0 & 0 & Das and Haque (2018) \\
Peru & 1 & 21.8 & 33.2 & 29.1 & 15.9 & 0 & 0 & 0 & Marin et al. (2018) \\
\hline
\end{tabular}

Note: $\operatorname{Tr}=$ Transition, Tv= Transversion, Ps= Polymorphic site 
Table 5. Characteristics of the cutting edges of the whale shark COI gene sequence by restriction enzyme

\begin{tabular}{|c|c|c|c|c|c|}
\hline Name & Sequence & Site length & Overhang & Frequency & Cut positions \\
\hline PsiI & TTATAA & 6 & Blunt & 1 & 114 \\
\hline ScaI & AGTACT & 6 & Blunt & 1 & 555 \\
\hline SspI & AATATT & 6 & Blunt & 1 & 576 \\
\hline ApaLI & GTGCAC & 6 & five_prime & 1 & 216 \\
\hline ApoI & RAATTY & 6 & five_prime & 1 & 414 \\
\hline BbvI & GCAGC & 5 & five_prime & 1 & 572 \\
\hline BclI & TGATCA & 6 & five_prime & 1 & 103 \\
\hline BseYI & CCCAGC & 6 & five_prime & 1 & 311 \\
\hline EcoP15I & CAGCAG & 6 & five_prime & 1 & 591 \\
\hline EcoRII & CCWGG & 5 & five_prime & 1 & 82 \\
\hline FauI & CCCGC & 5 & five_prime & 1 & 361 \\
\hline HindIII & AAGCTT & 6 & five_prime & 1 & 253 \\
\hline SfaNI & GCATC & 5 & five_prime & 1 & 383 \\
\hline SpeI & ACTAGT & 6 & five_prime & 1 & 196 \\
\hline TatI & WGTACW & 6 & five_prime & 1 & 553 \\
\hline TseI & GCWGC & 5 & five_prime & 1 & 560 \\
\hline VspI & ATTAAT & 6 & five_prime & 1 & 459 \\
\hline BseMI & CTCAG & 5 & three_prime & 1 & 64 \\
\hline PstI & CTGCAG & 6 & three_prime & 1 & 301 \\
\hline XhoII & RGATCY & 6 & five_prime & 2 & 86,631 \\
\hline AloI & GAACNNNNNNTCC & 7 & three_prime & 2 & 322,354 \\
\hline BsaXI & ACNNNNNCTCC & 6 & three_prime & 2 & 363,393 \\
\hline BseSI & GKGCMC & 6 & three_prime & 2 & 204,220 \\
\hline BsrI & ACTGG & 5 & three_prime & 2 & 167,551 \\
\hline Hin4I & GAYNNNNNVTC & 6 & three_prime & 2 & 621,653 \\
\hline MboII & GAAGA & 5 & three_prime & 2 & 47,142 \\
\hline SduI & GDGCHC & 6 & three_prime & 2 & 204,220 \\
\hline TaqII & GACCGA & 6 & three_prime & 2 & 577,603 \\
\hline TspDTI & ATGAA & 5 & three_prime & 4 & $264,408,433,534$ \\
\hline
\end{tabular}

Table 6. Mutations of the whale shark COI gene

\section{ID Sample}

No. nucleotide 284

Haplotype

WS ID 016, WS ID 069, WS ID 078, WS ID 122, WS ID 132, WS ID 137, WS ID 138, WS ID 140, WS ID 141, WS ID 146, WS ID 147, WS ID 148, WS ID 149, WS ID 150, HP 1, HP 9, HP A5, HP NUS31, HP NUS 41, HP NUS 42, HP NUS 48, HP NUS 49, HP NUS 59, HP NUS 63, HP NUS 347 , HP NUS 350

WS ID 047, HP NUS 355

Mutation type

$\mathrm{C}$

Transition

Table 7. Comparison of the genetic diversity between Cendrawasih Bay whale sharks and whale sharks from other parts of the IndoPacific Region.

\begin{tabular}{|c|c|c|c|c|c|c|}
\hline $\begin{array}{l}\text { Diversities/ } \\
\text { location }\end{array}$ & $\begin{array}{c}\text { No. } \\
\text { sample }\end{array}$ & $\begin{array}{c}\text { No. } \\
\text { haplotype }\end{array}$ & $\begin{array}{c}\text { No. } \\
\text { segregation } \\
\text { sites } \\
\end{array}$ & $\begin{array}{c}\text { Haplotype } \\
\text { diversity (Hd) }\end{array}$ & $\begin{array}{c}\text { Nucleotide } \\
\text { diversity (Pi) }\end{array}$ & $\begin{array}{c}\text { Average } \\
\text { differences } \\
\text { number, } \mathbf{K}\end{array}$ \\
\hline Cenderawasih Bay & 28 & 2 & 1 & 0.137 & 0.00025 & 0.13757 \\
\hline Taiwan & 6 & 1 & 0 & 0 & 0 & 0 \\
\hline Seychelles & 1 & 1 & $\mathrm{Na}$ & $\mathrm{Na}$ & $\mathrm{Na}$ & $\mathrm{Na}$ \\
\hline India & 5 & 3 & 6 & 0.700 & 0.004 & 2.400 \\
\hline Pakistan & 1 & 1 & $\mathrm{Na}$ & $\mathrm{Na}$ & $\mathrm{Na}$ & $\mathrm{Na}$ \\
\hline Philippines & 1 & 1 & $\mathrm{Na}$ & $\mathrm{Na}$ & $\mathrm{Na}$ & $\mathrm{Na}$ \\
\hline South Africa & 4 & 1 & 0 & 0 & 0 & 0 \\
\hline Australia & 2 & 1 & 0 & 0 & 0 & 0 \\
\hline Mozambique & 3 & 1 & 0 & 0 & 0 & 0 \\
\hline China & 1 & 1 & $\mathrm{Na}$ & $\mathrm{Na}$ & $\mathrm{Na}$ & $\mathrm{Na}$ \\
\hline United Arab Emirates & 1 & 1 & $\mathrm{Na}$ & $\mathrm{Na}$ & $\mathrm{Na}$ & $\mathrm{Na}$ \\
\hline Bangladesh & 1 & 1 & $\mathrm{Na}$ & $\mathrm{Na}$ & $\mathrm{Na}$ & $\mathrm{Na}$ \\
\hline Peru & 1 & 1 & $\mathrm{Na}$ & $\mathrm{Na}$ & $\mathrm{Na}$ & $\mathrm{Na}$ \\
\hline
\end{tabular}

Note: na is not analyzed because there is only one sample 


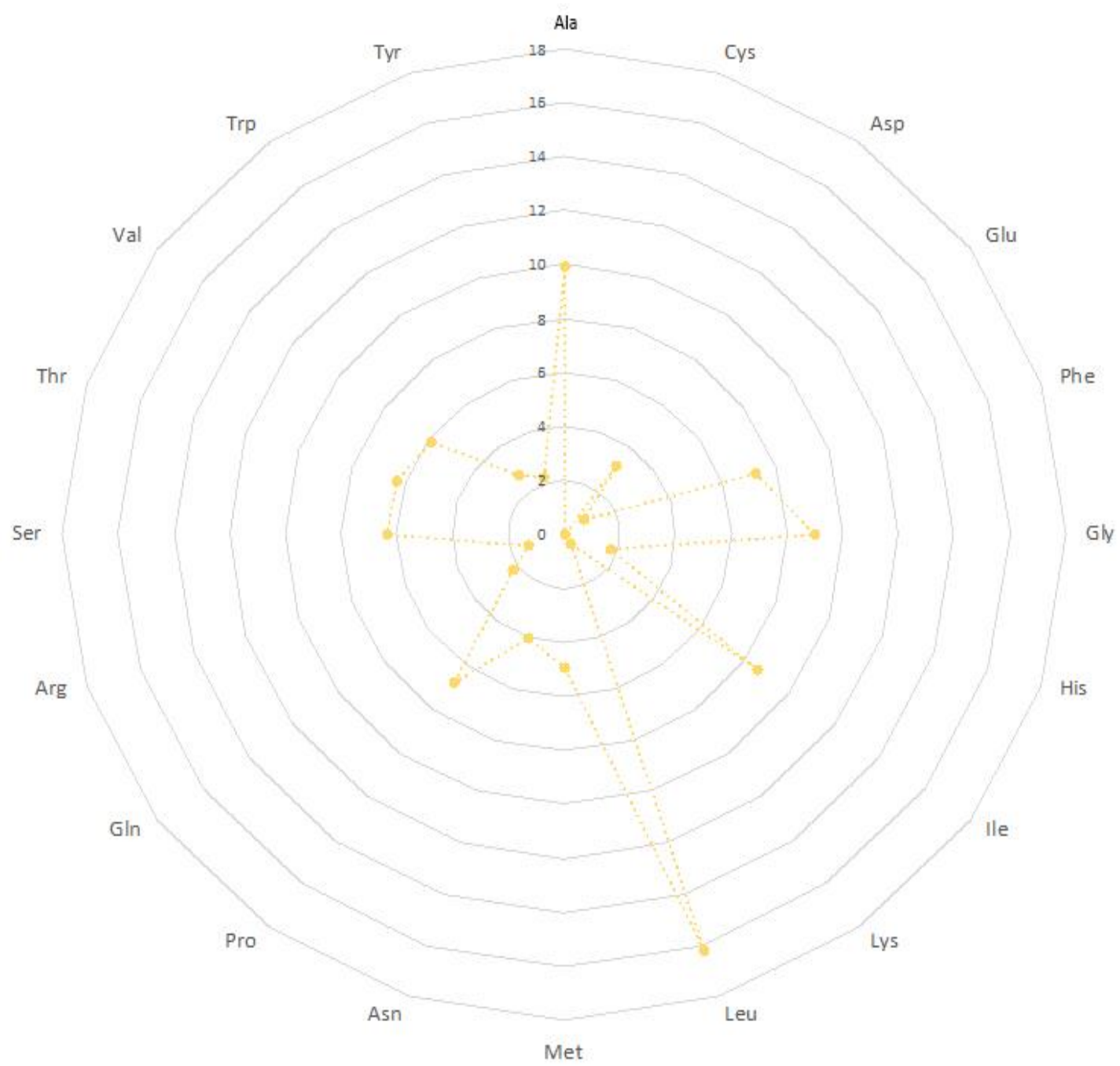

Figure 2. Relative amino acid composition of the protein coded by the COI gene fragment in the mitochondrial DNA of Cenderawasih Bay whale sharks

Table 8. Estimates of net evolutionary differences between populations of whale sharks in the world

\begin{tabular}{lccccccccccccc}
\hline \multicolumn{1}{c}{ Locations } & $\mathbf{1}$ & $\mathbf{2}$ & $\mathbf{3}$ & $\mathbf{4}$ & $\mathbf{5}$ & $\mathbf{6}$ & $\mathbf{7}$ & $\mathbf{8}$ & $\mathbf{9}$ & $\mathbf{1 0}$ & $\mathbf{1 1}$ & $\mathbf{1 2}$ & $\mathbf{1 3}$ \\
\hline 1. India & & 0.00 & 0.00 & 0.00 & 0.00 & 0.00 & 0.00 & 0.00 & 0.00 & 0.00 & 78.95 & 0.00 & 0.00 \\
2. Seychelles & 0.00 & & 0.00 & 0.00 & 0.00 & 0.00 & 0.00 & 0.00 & 0.00 & 0.00 & 78.96 & 0.00 & 0.00 \\
3. Mozambique & 0.00 & 0.00 & & 0.00 & 0.00 & 0.00 & 0.00 & 0.00 & 0.00 & 0.00 & 78.96 & 0.00 & 0.00 \\
4. South_Africa & 0.00 & 0.00 & 0.00 & & 0.00 & 0.00 & 0.00 & 0.00 & 0.00 & 0.00 & 78.96 & 0.00 & 0.00 \\
5. Australia & 0.00 & 0.00 & 0.00 & 0.00 & & 0.00 & 0.00 & 0.00 & 0.00 & 0.00 & 78.96 & 0.00 & 0.00 \\
6. Philippines & 0.00 & 0.00 & 0.00 & 0.00 & 0.00 & & 0.00 & 0.00 & 0.00 & 0.00 & 78.96 & 0.00 & 0.00 \\
7. CB-Indonesia & 0.00 & 0.00 & 0.00 & 0.00 & 0.00 & 0.00 & & 0.00 & 0.00 & 0.00 & 78.96 & 0.00 & 0.00 \\
8. China & 0.00 & 0.00 & 0.00 & 0.00 & 0.00 & 0.00 & 0.00 & & 0.00 & 0.00 & 78.96 & 0.00 & 0.00 \\
9. Taiwan & 0.00 & 0.00 & 0.00 & 0.00 & 0.00 & 0.00 & 0.00 & 0.00 & & 0.00 & 78.96 & 0.00 & 0.00 \\
10. UAE & 0.00 & 0.00 & 0.00 & 0.00 & 0.00 & 0.00 & 0.00 & 0.00 & 0.00 & & 78.96 & 0.00 & 0.00 \\
11. Pakistan & 8.38 & 8.38 & 8.38 & 8.38 & 8.38 & 8.38 & 8.38 & 8.38 & 8.38 & 8.38 & & 78.96 & 78.96 \\
12. Peru & 0.00 & 0.00 & 0.00 & 0.00 & 0.00 & 0.00 & 0.00 & 0.00 & 0.00 & 0.00 & 8.38 & & 0.00 \\
13. Bangladesh & 0.00 & 0.00 & 0.00 & 0.00 & 0.00 & 0.00 & 0.00 & 0.00 & 0.00 & 0.00 & 8.38 & 0.00 \\
\hline
\end{tabular}

Note: the number below the diagonal is the difference in the number of bases. While the number above diagonal is the approximate standard error obtained through the bootstrap procedure (1000 replication). The analysis involved 55 nucleotide sequences from various countries including Indonesia with samples of whale sharks from Cenderawasih Bay (CB-Indonesia). 


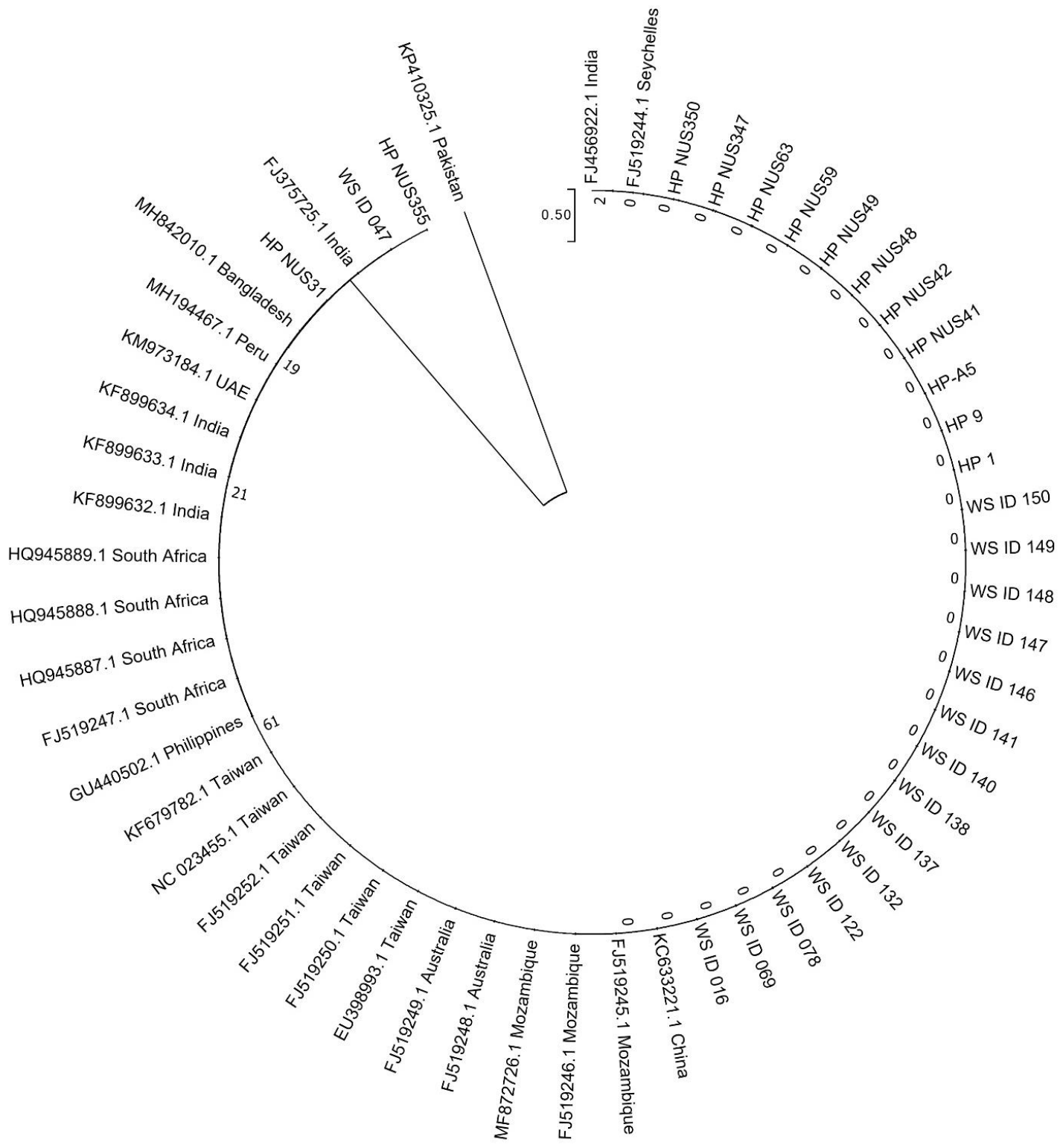

Figure 3. Combined phylogenetic tree: a phylogenetic tree constructed using Tamura 3 parameters, maximum likelihood, and bootstrap testing with 1000 replications. All individual whale sharks from Cenderawasih Bay with IDs: WS and HP.

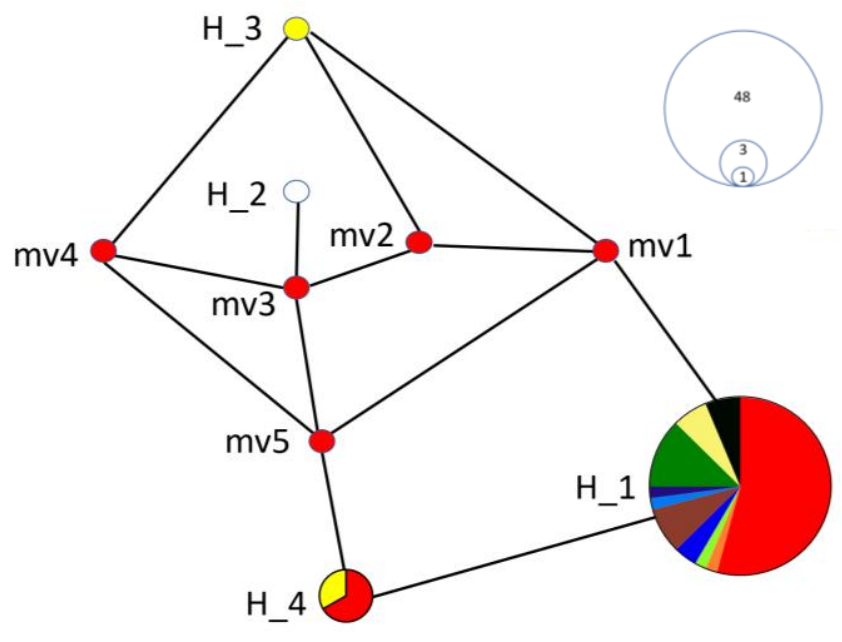

Figure 4. Haptotype network of whale shark in the Indo-Pacific region including Cenderawasih Bay. Circles represent the type of haplotype with the colour denoting the population where it is found: Cenderawasih $\mathrm{Bay}=$ red, Mozambique $=$ black, India $=$ yellow, Taiwan = green, Seychelles $=$ purple, Philippines $=$ light blue, South Africa = brown, Australia = dark blue, China = light green, $\mathrm{UAE}=$ light brown, Pakistan $=$ white. $\mathrm{H} 1$ was haplotype 1 consist of ten populations of whale shark from Cenderawsih Bay, Mozambique, India, Taiwan, Seychelles, Philippines, South Africa, Australia, China, and UAE. H2 was haplotype 2 that found only in India. H3 was haplotype 3 that found only in Pakistan. H4 was haplotype 4 that consist of two populations from Cenderawasih Bay and India. The size of the circle accounting for its frequency. The lengths of the lines connecting the haplotypes refer the distance of relatedness with the numbered steps usually representing one bp change per step. Red rectangle $(\mathrm{mv})=$ median vector that represents unsampled sequences or extinct ancestral sequences. 
In total, there were four haplotypes identified in the Indo-Pacific whale shark namely $\mathrm{H} 1, \mathrm{H} 2, \mathrm{H} 3$, and $\mathrm{H} 4$. Two haplotypes ( $\mathrm{H} 1$ and $\mathrm{H} 4)$ are general haplotype that found on Cenderawasih Bay and other populations in Indo-Pacific such as Mozambique, India, Taiwan, Seychelles, Philippines, South Africa, Australia, China, and UAE. Whilst two other haplotypes ( $\mathrm{H} 2$ and $\mathrm{H} 3)$ were specific haplotypes that only found in one population at Pakistan and India respectively. The network of haplotypes between whale sharks in the Indo-Pacific including Cenderawasih Bay is shown in Figure 4.

\section{Discussion}

The CO1 gene is a mitochondrial gene that is widely used for resolution at species and genus level, perhaps best known as a hypothetical species identifier in the Barcode of Life Project (Hebert et al. 2003a,b). Identification using DNA barcodes is a genetic sequence based approach, based on standard gene regions. Moreover, DNA barcode reference records are supported by additional information networks, allowing barcode sequences to be reviewed independently (Ratnasingham and Hebert 2007). Identification of whale sharks using genetic information from individual animals can also be based on core DNA microsatellite markers (Palsboll et al. 1997). Another method for keeping track of individual animals is by photo identification (Karlsson et al. 2005). Previous reearchers (Tania 2015; Suruan 2017) have used photo identification to track individual whale sharks, and their results are consistent with those from the barcoding approach used in this study.

All samples taken from whale sharks in Cenderawasih Bay were identified as coming from one species, namely Rhincodon typus (Smith 1828) with a percentage similarity of $99-100 \%$. The number of sample sequences analyzed in this study were 28 sequences. This number exceeds the number of sequences (27) previously deposited in GenBank (https: //www.ncbi.nlm.nih.gov/nuccore). Generally speaking, genetic studies that specifically use COI markers of $R$. typus are still quite rare. The reason for the limited number of sequences deposited in GenBank is because of the small number of researchers studying whale sharks in global waters.

\section{Genetic characteristics}

The total length of the nucleotide sequences of the whale shark COI gene fragment in Cenderawasih Bay is different from the sequence length in previous studies. The average gene fragment analyzed was only $556 \mathrm{bp}$ (Toha et al. 2016). In previously determined whale shark sequences from across the Indo-Pacific region deposited in GenBank, the length of the COI sequences (listed in Table 3) ranged from 514 to 705 bp (Ward et al. 2008, Wong et al. 2009, Hastings and Burton 2010, Bineesh et al. 2013; Steinke et al. 2016). The variation in the length of the gene fragment is mainly due to PCR primer differences and PCR amplicon concentrations. The mitochondrial DNA of whale sharks consists of a double-stranded ring structure consisting of $16,875 \mathrm{bp}$ according to Alam et al. (2014) or $16,928 \mathrm{pb}$ according to Chen et al. (2014). The COI whale gene gene is one of the genes in this mitochondrial genome, within a gene fragment $1556 \mathrm{pb}$, in length, between nucleotides No. 5479 and 7035 (Alam et al. 2014).

There are differences in the estimated number of nucleotide bases in the whale shark COI sequences sampled from different parts of the world (Table 3), especially between whale sharks from Pakistan (705 bp) and whale sharks from other countries (ranging from 514 to 674 bp), including those from Cenderawasih Bay (669 bp). Toha (2016) report quite different results for Cenderwasih whale shark COI sequence lengths ranging from 382 to 731 bp with a GC and AT content of $38.10 \%$ and $61.89 \%$, respectively. In our study, the nucleotide composition of $\mathrm{A}$, $\mathrm{T}, \mathrm{G}$, and $\mathrm{C}$ found in the COI gene fragments of whale sharks in Teluk Cenderawasih was similar to those determined for whale sharks from various other locations in the Indo-Pacific region. It appears that the $\mathrm{G}+\mathrm{C}$ content of individual whale shark sequences in some countries is between 43.02 and $43.39 \%$, and the $\mathrm{A}+\mathrm{T}$ content between 56.61 and 56.98. This result is similar to our results for whale sharks in Cenderawasih Bay. The $\mathrm{G}+\mathrm{C}$ content of all our samples averaged $43.05 \%$, i.e. smaller than the average $\mathrm{A}+\mathrm{T}$ content of $56.95 \%$. Alam et al. (2014) found the percentage of GC content amounted to about $38 \%$ of the complete whale shark mitogenome (mitochondrial genome) but different results were reported by Castro et al. (2007) and Castro (2009) for the control region gene markers of the mitochondrial DNA.

In this study we detected within the Cenderawasih Bay population only one polymorphism of the COI gene fragment, based on a single transition mutation. This contrasts markedly with the results of Mekan et al. (2008) who identified 55 polymorphic sides with 35 substitutions (32 transitions and 3 transversions) in the mtDNA control region marker ( 1,000 bp).

Nucleotide changes in the mtDNA COI gene in Cenderawasih Bay whale sharks are few and slow. Mutations accumulate at different rates under different selection pressures and migration rates. The very low level of accumulated genetic change in the COI gene fragment of Cenderawasih Bay whale sharks, suggest limited isolation of the Cenderawsih population from the global population and little selection pressure, leading to a very slow rates of evolutionary change.

Low levels of mutation accumulation suggests that the Cenderawasih Bay whale sharks are able to migrate across the wider ocean for mating. High intermixing of the Cenderawasih Bay whale shark by migration to and from other regions is thus the likely cause of the low level of gene diversity in the Bay. Inter-population migration resulting in gene-flow between regions was also inferred by (Schmidt et al. 2009, 2010) based on the evidence from whole genome microsatellite data from whale sharkpopulations in the Indian, East Pacific and the Carribean regions.

According to Simon (1991), the CO1 gene is one of the mtDNA genes that evolved most recently. The COI gene is reported to have a potential for a low mutation rate compared to the cytochrome $\mathrm{b}$ gene (da Fonseca et al. 2008). Mitochondrial DNA is normally inherited 
exclusively from the mother (female lineage) and has a relatively higher mutation rate than nuclear DNA (in the nucleus) (Solihin 1994). The structure of the COI sequence of whale sharks has no gaps, insertions or deletions and does not have a stop codon. This shows that this sequence is a structural gene (Toha 2011). The whale shark's COI gene is located between the tRNA gene (bp No. 5408 to bp 5477) for the amino acid Tyrosine (tRNA-Tyr) and the tRNA gene (bp No. 7039 to pp7109) for the amino acid Serine (tRNA-Ser) (Alam et al. 2013). This gene encodes unit I cytochrome oxidase protein which plays a role in the electron transfer process in ATP synthesis in mitochondria. The CO1 gene is the most conservative protein coding gene in mtDNA (Brown 1985). Well-conserved genes can be used as a basis for tracking common origins, whereas nonconserved genes, which are rapidly evolving genes, are more useful in comparing new strains.

Type II restriction enzymes cut the COI shark whale gene fragments in to various short nucleotide sequences. Type II endonucleases recognize specific DNA sequences and cut gene fragments at specific locations inside or adjacent to the recognition site to produce 5-phosphate and 3-hydroxyl ends (Halford 2001, Pingoud and Jeltsch 2001, Roberts et al. 2003). Restriction enzymes are an essential tool in determining nucleotide sequences for a wide variety of research purposes. For example, Mendonza et al. (2009) used the technique of PCR-RFLP (polymerase chain reaction restriction fragment length polymorphisms) to distinguish between the shark species Rhizoprionodon lalandii and $R$. porosus (Elasmobranchii, Carcharhinidae). The RFLPs are identified by differences in the distances travelled by the restriction fragments in gel electrophoresis. This molecular technique is used for DNA fingerprint identification (Toha 2001, 2011).

The genetic diversity (nucleotides ) of Cenderawasih Bay whale sharks detected in our study was relatively low. Based on such lack of genetic differentiation, Meekan et al. (2017) proposed a single panmictic metapopulation for the species as a whole with "limited genetic structuring across the species range", but like Vignaud et al. (2014), they also found some evidence of "the presence of a genetically unique and potentially isolated population in the Atlantic Ocean".

This study only identified two haplotypes from all 28 whale sharkes sampled in Cenderawasih Bay. The first haplotype bore $100 \%$ similarity with sequences from other Indo-Pacific locations deposited in GenBank, while haplotype 2 had $99 \%$ similarity with a whale shark accession number FJ376726.1 (from India). All samples had the same sequence except samples with numbers WS_ID-047 and HP-NUS-355. Overall, the Indo-Pacific whale shark COI markers deposited in GenBank including Cenderawasih Bay whale shark only have four haplotypes (Figure 4).

Different findings were reported by Castro et al. (2007) who based their genetic analysis on sequences in the mitochondrial DNA control region. They identified 44 haplotypes among 70 samples of $R$. typus from around the world. Likewise, Ramírez-Macías et al. (2007) observed 14 haplotypes for the mtDNA control region among 36 individual whale sharks in the Gulf of California, Mexico. Importantly, our own result is also much lower than the findings of Toha et al. (2016) who observed 7 haplotypes of the COI gene marker in 31 individual whale sharks from Cenderawasih Bay. These different findings are a result of differences in the particular gene marker investigated and the length of the sequences analyzed by the researchers.

\section{Genetic connectivity}

The AMOVA analysis revealed no significant clustering of the genetic variation among the GenBank sequences from the Indian and Pacific Ocean locations (including our's from Cenderawasih Bay), other than a single outlier-the one sequence from Pakistan (which requires explanation). Very little overall variation (only $2.45 \%$ ) was observed in the GenBank COI sequences. The population from Cenderawasih Bay contributed negligible variation to the total.

According to Sakai et al. (2001) genetic diversity determines the capacity of populations to adapt to new environmental conditions. Genetic diversity also plays an important role in determining their potential to be invasive (Drake and Lodge 2006; Lavergne and Molofsky, 2007). Populations with low genetic diversity are more vulnerable to new pests or diseases, pollution, climate change and habitat destruction from human activities or other disasters. The inability to adapt to changing conditions can increase the risk of extinction. A population with high genetic diversity has a greater chance to survive or excel. If genetic diversity is very low, there are no individuals in the population to adjust to the new environmental conditions. The population can become extinct.

The results of our study indicate that the Cenderawasih Bay whale sharks and whale sharks from other waters in the Indo-Pacific region have a very close genetic relationship. It is assumed that all members of the species originate from a common ancestral population.

According to Schmidt (2014) genetic analysis based on mtDNA sequences support the inference of widespread migration of whale sharks across the tropical oceans of the world. Satellite tracking data has also revealed that migration of the Cenderawasih Bay whale sharks is quite extensive (Stewart 2011). Tracking satellites from other regions also show that the migration of whale sharks is wide, with a global reach (Norman 2005), and support the findings of gene flow between populations (Castro et al. 2007).

This study supports the inference that Cenderawasih Bay whale sharks have a close genetic relationship with Indo-Pacific whale sharks as a whole. Based on COI haplotype distribution, there is no evidence of partioning of the whale shark population within Cendrawasih Bay or between whale sharks in the Bay and other locations in the Indo-Pacific (Toha et al. 2016). According to Kennedy (1998) if two organisms are closely related, the DNA will be very similar. In this study it appears that there is a very close relationship between individual whale sharks of Cenderawasih Bay, indicating kinship based on common ancestors. 
The evolutionary relationship between the Cenderawasih Bay whale sharks and the Indo-Pacific as a whole appears to be very close, despite the wide geographic distances that separate the sampling locations represented in GenBank. This shows that there is a history of gene flow between populations (Schmidt et al. 2009). This result is supported by a combination of research approaches related to the global migration of whale sharks (see Sequeira et al. 2013). Nevertheless, there is some suggestion in the GenBank COI sequences of incipient evolutionary partitioning between Indian and Pakistani whale sharks and the rest of the Indo-Pacific population based on the apparent number of mutations in those locations (see Tables 7 and 8 and Figure 4). This requires further investigation.

Cenderawasih Bay in West Papua/ Papua is a very favourable environment for the whale shark (Rhincodon typus). Although the evidence from this and other studies (eg. Toha 2016) suggests that the whale sharks in the Bay are not genetically distinct from those in other parts of the Indo-Pacific distribution, the population in Cenderawasih Bay is dominated by young males with a a body size between 3-6 meters (Himawan et al. 2015). This indicates that Cenderawasih Bay is an important habitat for whale sharks approaching breeding age ,and that it is is therefore vital to protect their populations in this unique and beautiful part of the world's oceans.

\section{ACKNOWLEDGEMENTS}

This research took place in collaboration with Teluk Cenderawasih National Park Office, the Faculty of Fisheries and Marine Science, University of Papua and the WWF-Indonesia region of Cenderawasih Bay. Thank you to the Teluk Cenderawasih National Park Office for permission and for sample collection. We also thank WWF-Indonesia for funding the research. Thank you to the UNIPA Genetic Laboratory for data compilation and for the laboratory work.

\section{REFERENCES}

Ahonen H, Harcourt RG, Stow AJ. 2009. Nuclear and mitochondrial DNA reveals isolation ofimperilled grey nurse shark populations (Carchariastaurus). Mol Ecol 18, 4409-4421. DOI: 10.1111/j.1365294X.2009.04377.x

Alam MT, Petit RA III, Read TD, Dove AD. 2014. The complete mitochondrial genome sequence of the world's largest fish, the whale shark (Rhincodon typus), and its comparison with those of related shark species. Gene 539 (1): 44-49.

Anna Z. 2016. Valuasi ekonomi pada kegiatan wisata hiu paus di Taman Nasional Teluk Cenderawasih (TNTC) dengan menggunakan pendekatan Travel Cost Method dan Contingent Value Method. Research Report. Yayasan WWF Indonesia. 86 p. [Indonesian]

Azourmanian Z, Holmberg J, Norman B. 2005. An astronomical patternmatching algorithm for computer aided identification of whale sharks Rhincodon typus. J Appl Ecol 42: 999-1011.

Baldwin CC, Mounts JH, Smith DG, Weigt LA. 2008. Genetic identification and color descriptions of early life-history stages of Belizean Phaeoptyx and Astrapogon (Teleostei: Apogonidae) with comments on identification of adult Phaeoptyx. Zootaxa 2008: 1-22.
Bawole R, Sala R, Suruan SS, Numberi A, Suhaemi. 2018. Perencanaan spasial whale shark sanctuary. Research Report. WWF-Indonesia, Jakarta.

Bineesh KK, Akhilesh KV, Abdussamad EM, Sajeela KA, Pillai NGK, Basheer VS, Gopalakrishnan A, Jena JK. 2013. Direct Submission. Submitted (25-NOV-2013) NBFGR Kochi Unit, National Bureau of Fish Genetic Resources, CMFRI, Kochi, Kerala, India

Brown WM. 1985. The mitochondrial genome of animals. In: Macintyre RJ (ed.) Molecular Evolutionary Genetics, Plenum Press, New York.

Carpenter KE, Barber PH, Crandall ED, Ablan-Lagman MCA, Ambariyanto, Mahardika N, Manjaji-Matsumoto MB, JuinioMeñez MA, Santos MD, Starger C, Toha AHA. 2011. Comparative phylogeography of the coral triangle and implications for marine management. Mar Biol. DOI: 10.1155/2011/396982.

Castro ALF, Stewart BS, Wilson SG, Hueter RE, Meekan MG, Motta PJ, Bowen BW, Karl SA. 2007. Population genetic structure of Earth's largest fish, the whale shark (Rhincodon typus). Mol Ecol 16: 51835192. DOI: 10.1111/j.1365-294X.2007.03597.x.

Castro ALF. 2009. Use of Molecular Tools on Surveys of Genetic Variation and Population Structure in Three Species of Sharks. [Dissertation]. University of South Florida, Tampa, FL.

Chen X, Ai W, Pan L, Shi X1. 2014. Complete mitochondrial genome of the largest living fish: whale shark Rhincodon typus (Orectolobiformes: Rhincodontidae). Mitochondrial DNA A DNA Mapp Seq Anal 27 (1): 425-6. DOI: 10.3109/19401736.2014.898288.

CITES. 2002. CITES Appendix II nomination of the Whale Shark, Rhincodon typus. Proposal 12.35. Santiago, Chile, CITES Resolutions of the conference of the parties in effect after the 12th Meeting. On line: http: //www.cites.org/eng/cop/12/prop/E12P35.pdf.

da Fonseca RR, Johnson WE, O'Brien SJ, Ramos MJ, Antunes A. 2008. The adaptive evolution of the mammalian mitochondrial genome. BMC Genom 9: 119. DOI: 10.1186/1471-2164-9-119.

Dailami M, Santi D, Murtihapsari, Abubakar H, Toha AHA. 2018. Analisis genetik fragmen gen sitrokrom oksidase sub unit 1 dari Cirrhilabrus cf ryukyuensis Ishikawa 1904 (Labridae) asal Teluk Cenderawasih dan Raja Ampat. Jurnal Iktiologi Indonesia 18 (3): 209-222. [Indonesian]

Das SA, Haque AB. 2018. Direct Submission, Submitted (05-SEP-2018) Biochemistry and Molecular Biology. University of Dhaka, Dhaka, Bangladesh.

DeBoer TS, Naguit MRA, Erdmann MV, Ablan-Lagman MC, Ambariyanto, Carpenter KE, Toha AHA, Barber PH. 2014a. Concordant phylogenetic patterns inferred from mitochondrial and microsatellite DNA in the giant clam, Tridacna crocea. Bull Mar Biol 90 (1): 301-329. DOI: 10.5343/bms.2013.1002.

DeBoer TS, Naguit MRA, Erdmann MV, Ma Ablan-Lagman MC, Ambariyanto, Carpenter KE, Toha AHA, Barber PH. 2014b. Concordance between phylogeographic and biogeographic boundaries in the Coral Triangle: conservation implications based on comparative analyses of multiple giant clam species. Bull Mar Sci 90 (1): 277-300. DOI: $10.5343 / \mathrm{bms} .2013 .1003$.

Drake JM, Lodge DM. 2006. Allee effects, propagule pressure and the probability of establishment: risk analysis for biological invasions. Biol Invasions 8: 365-375.

Excoffier L, Lischer HEL.2010. Arlequin suite ver 3.5: A new series of programs to perform population genetics analyses under Linux and Windows. Molecular Ecology Resources 10 (3): 564-567. DOI: 10.1111/j.1755-0998.2010.02847.x

Fowler SL. 2000. Whale Shark (Rhincodon typus): policy and research scoping study. Nature Conservation Bureau, http: Ilwww.whalesharkproject.org/do_download. asp?did=26782.

Gopalakrishnan A, Sajeela KA, Divya PR, Manoj P, Vipindas PK, Lakra WS. 2008. Direct Submission, Submitted (12-NOV-2008) National Bureau of Fish Genetic Resources (NBFGR Cochin Unit), CMFRI, Kochi, Kerala, India

Halford SE. 2001. Hopping, jumping and looping by restriction enzymes. Biochem Soc Trans 29: 363-374.

Hastings P, Burton R. 2010. Marine Fishes of California. Philippines: Pamilican Island, Bohol. Direct Submission. Submitted (12-JAN2010) Scripps Institution of Oceanography, University of California San Diego, La Jolla, CA, USA.

Hebert PDN, Cywinska A, Ball SL, deWaard JR. 2003a. Biological identification through DNA barcodes. Proc R Soc B Biol Sci 270: 313-321. 
Hebert PDN, Ratnasingham S, DeWaard JR. 2003b. Barcoding animal life: cytochrome $\mathrm{c}$ oxidase subunit 1 divergences among closely related species. Proc R Soc B Biol Sci 270, S96-S99.

Himawan MR, Tania C, Noor BA, Wijonarno A, Subhan B, Madduppa H. 2015. Sex and size range composition of whale shark (Rhincodon typus) and their sighting behaviour in relation with fishermen lift-net within Cenderawasih Bay National Park, Indonesia. AACL Bioflux 8 (2): 123-133.

Hoegh-Guldberg O, Hoegh-Guldberg H, Veron JEN, Green A, Gomez ED, Lough J, King M, Ambariyanto, Hansen L, Cinner J, Dews G, Russ G, Schuttenberg HZ, Penaflor EL, Eakin CM, Christensen TRL, Abben M, Areki F, Kosaka RA, Tewfik A, Oliver J. 2009. The Coral Triangle and Climate Change: Ecosystems, people and societies at risk. WWF Australia, Brisbane,

Jabado RW, Al Ghais SM, Hamza W, Shivji MS, Henderson AC. 2014 Shark diversity in the Arabian/Persian Gulf higher than previously thought: insights based on species composition of shark landings in the United Arab Emirates. Mar Biodivers. DOI 10.1007/s12526-0140275-7.

Kanwal S, Shehzad A, Baig HS, Ansari MA, Khan OY. 2015. DNA Barcoding of Fish from North Arabian Sea. University of Punjab, Lahore, Pakistan.

Karlsson O, Hiby L, Lundberg T, Jussi M, Jussi I, Helander B. 2005. Photo-identification, site fidelity, and movement of female gray seals (Halichoerus grypus) between haul-outs in the Baltic Sea. Ambio 34: 628-634.

Kennedy D, Alberts B, Ezell D, et al. 1998. Teaching About Evolution and the Nature of Science. The National Academy Of Sciences, Washington DC.

Kerr KC, Birks SM, Kalyakin MV, Red'kin YA, Koblik EA, Hebert PD. 2009. Filling the gap-COI barcode resolution in eastern Palearctic birds. Front Zool 6 (1): 29. DOI: 10.1186/1742-9994-6-29.

Kunarso. 2016. Faktor-faktor oseanografi di lokasi fishing ground ikan puri (Stolephorus spp.) yang berkaitan dengan kemunculan ikan hiu paus (Rhincodon typus) DI kawasan wisata Perairan Kuatisore Teluk Cendrawasih. Research Report. Yayasan WWF Indonesia. [Indonesian]

Lavergne S, Molofsky J. 2007. Increased genetic variation and evolutionary potential drive the success of an invasive grass. Proc Natl Acad Sci USA 104: 3883-3888.

Librado P, Rozas J. 2009. DnaSP v5: A software for comprehensive analysis of DNA polymorphism data. Bioinformatics 25: 1451-1452.

Marin A, Serna J, Robles C, Ramirez B, Reyes-Flores LE, ZeladaMazmela E, Sotil G, Alfaro R. 2018. A glimpse into the genetic diversity of the Peruvian seafood sector: Unveiling species substitution, mislabeling and trade of threatened species. PLoS ONE 13 (11): e0206596. DOI: 10.1371/journal.pone.0206596.

Marliana SN. 2016. Kajian ekologis pakan alami hiu paus Rhincodon typus Smith, 1828 dalam konteks aktivitas perikanan di Taman Nasional Teluk Cenderawasih. Research Report. Yayasan WWF Indonesia, Jakarta. [Indonesian]

Meekan M, Austin CM, Tan MH, Wei N-WV, Miller A, Pierce SJ, Rowat D, Stevens G, Davies TK, Ponzo A, Gan HM. 2018. iDNA at sea: Recovery of whale shark (Rhincodon typus) mitochondrial DNA sequences from the whale shark copepod (pandarus rhincodonicus) confirms global population structure. Front Mar Sci 4. DOI: 10.3389/fmars.2017.00420

Mendonça F, Hashimoto D, Porto Foresti F, Oliveira C, Gadig O, Foresti F. 2009. Identification of the shark species Rhizoprionodon lalandii and $R$. porosus (Elasmobranchii, Carcharhinidae) by multiplex PCR and PCR RFLP techniques. Mol Ecol Res 9: 771-773. DOI: 10.1111/j.1755-0998.2009.02524.x

Norman B. 2005. Rhincodon typus. In: IUCN 2013. IUCN Red List of Threatened Species. Version 2013.2. (www.iucnredlist.org).

Palsboll PJ. 1997. Genetic tagging: contemporary molecular ecology. Biol J Linn Soc 68: 3-22. DOI: 10.1111/j.1095-8312.1999.tb01155.x

Pierce SJ, Norman B. 2016. Rhincodon typus. The IUCN Red List of Threatened Species 2016: e.T19488A2365291. DOI: 10.2305/IUCN.UK.2016-1.RLTS.T19488A2365291.en. [6 April 2020].

Pingoud A, Jeltsch A. 2001. Structure and function of type II restriction endonucleases. Nucleic Acids Res 29 (18): 3705-3727. DOI: 10.1093/nar/29.18.3705

Pranata B, Fadjar M, Irnawati F, Toha AH, Jeni. 2018b. Phylogeny of the spiny lobster Panulirus versicolor in Cenderawasih Bay, Papua, Indonesia. AACL Bioflux 11 (4): 1015-1024.
Pranata B. Fadjar M, Iranawati F, Toha HA, Jeni. 2018a. Spiny lobster Panulirus versicolor phylogenetic and genetic in Lombok waters, West Nusa Tenggara, Indonesia. Biotika 1 (20): 37-43. [Indonesian]

Pravin P. 2000. Whale Shark in the Indian Coast. Conserv Curr Sci 79 (3): 310-315.

Prihadi DJ. 2016. Analisis kesesuaian dan daya dukung lingkungan pada wisata hiu paus (Rhincodon typus) di Taman Nasional Teluk Cenderawasih (TNTC), Kabupaten Nabire. Laporan Penelitian. Yayasan WWF Indonesia, Jakarta. [Indonesian]

Rakhee C, Sajeela KA, Rekha JN, Gopalakrishnan A, Basheer VS, Shoba JK, Joe K, Vijayan KK, Lakra WS. 2008. Direct Submission. Submitted (10-OCT-2008) National Bureau of Fish Genetic Resources (NBFGR Cochin Unit), CMFRI, Kochi, Kerala, India.

Ramírez-Macías D, Vázquez-Juárez R, Galván-Magaña F, Munguía-Vega A. 2007. Variations of the mitochondrial control region sequence in whale sharks (Rhincodon typus) from the Gulf of California, Mexico. Fish Res 84: 87-95. DOI: 10.1016/j.fishres.2006.11.03

Ratnasingham S, Hebert PDN. 2007. BOLD: The Barcode of Life Data System (http: //www.barcodinglife.org). Mol Ecol Notes 7: 355-364.

Rezzolla D, SToRai T. 2010. "Whale Shark Expedition": Observations on Rhincodon typus from Arta Bay, Gulf of Tadjoura, Djibouti Republic, Southern Red Sea. Cybium 34 (2): 195-206.

Roberts RJ, Belfort M, Bestor T, Bhagwat AS, Bickle TA, Bitinaite J, Blumenthal RM, Degtyarev SK, Dryden DT, Dybvig K, Firman K, Gromova ES, Gumport RI, Halford SE, Hattman S, Heitman J, Hornby DP, Janulaitis A, Jeltsch A, Josephsen J, Kiss A, Klaenhammer TR, Kobayashi I, Kong H, Kruger DH, Lacks S, Marinus MG, Miyahara M, Morgan RD, Murray NE, Nagaraja V, Piekarowicz A, Pingoud A, Raleigh E, Rao DN, Reich N, Repin VE, Selker EU, Shaw PC, Stein DC, Stoddard BL, Szybalski W, Trautner TA, van Etten JL, Vitor JM, Wilson GG, Xu SY. 2003. A nomenclature for restriction enzymes, DNA methyltransferases, homing endonucleases and their genes. Nucleic Acids Res 31: 18051812. DOI: $10.1093 / \mathrm{nar} / \mathrm{gkg} 274$

Sakai AK, Allendorf FW, Holt JS, Lodge DM, Molofsky J, With KA, Baughman S, Cabin RJ, Cohen JE, Ellstrand NC, McCauley DE, O'Neil P, Parker IM, Thompson JN, Weller SG. 2001. The population biology of invasive species. Ann Rev Ecol Evol Syst 32: 305-332. DOI: 10.1146/annurev.ecolsys.32.081501.114037

Saleky D, Setyobudiandi I, Toha AHA, Takdir M, Madduppa H. 2016. Length-weight relationship and population genetic of two marine gastropods species (Turbinidae: Turbo sparverius and Turbo bruneus) in the Bird Head's Seascape Papua, Indonesia. Biodiversitas 17 (1): 208-217. DOI: 10.13057/biodiv/d170130.

Schmidt J. 2014. Population and reproductive genetics in the whale shark (Rhincodon typus). http: //www.uic.edu/labs/schmidtlab/res4.shtml

Schmidt JV, Chen CC, Sheikh SI, Meekan MG, Norman BM, Joung SJ. 2010. Paternity analysis in a litter of whale shark embryos. Endang Sp Res 12: 117-124. DOI: 10.3354/esr00300.

Schmidt JV, Schmidt CL, Ozer F, Ernst RE, Feldheim KA, Ashley MV, Levine M. 2009. Low genetic differentiation across three major ocean populations of the whale shark, Rhincodon typus. PlosOne 4 (4): 1-9: e4988.DOI: 10.1371/journal.pone.00004988.

Sequeira AMM, Mellin C, Meekan MG, Sims DW, Bradshaw CJA. 2013. Inferred global connectivity of whale shark Rhincodon typus populations. J Fish Biol 82: 367-389. DOI: 10.1111/jfb.12017.

Simon C. 1991. Molecular systematics at the species boundary: exploiting conserved and variable regions of the mitochondrial genome of animals via direct sequencing from amplified DNA. In: Hewitt GM, Johnston AWB, Young JPW. (ed.). Molecular Techtriques in Tnxonomy. Nato Advanced Studies Institute, Series H: Cell Biology. Springer Verlag, Berlin.

Smith A. 1828. Descriptions of new, or imperfectly known objects of the animal kingdom, found in the south of Africa. S Afr Comm Adv 3: 2.

Solihin DD. 1994. Ulas balik. Peran DNA Mitokondria (mtDNA) dalam Studi Keragaman Genetik dan Biologi populasi pada Hewan. Hayati 1 (1): 1-4. [Indonesian]

Steinke D, Connell AD, Hebert PD. 2016. Linking adults and immatures of South African marine fishes. Genome 59 (11): 959-967.

Stewart BS. 2011. Workshop and Monitoring Training for Whale Sharks in Cendrawasih Bay National Park, West Papua 2-7 May 2011, Nabire, Papua. Hubbs-Sea World Research Institute Technical Report 2011-375: 1-27.

Suruan SS. 2017. Struktur populasi dan tingkah laku hiu paus (Rhincodon typus) di Perairan Kwatisore, Kabupaten Nabire, Provinsi Papua. [Thesis]. IPB, Bogor. [Indonesian] 
Tamura K, Stecher G, Peterson D, Filipski A, Kumar S. 2013. MEGA6: Molecular Evolutionary Genetics Analysis version 6.0. Mol Biol Evol 30: $2725-2729$.

Tania C, Noor BA. 2014. Pemanatauan Hiu Paus di Taman Nasional Teluk Cenderawasih dan WWF-Indonesia, Jakarta. [Indonesian]

Tania C, Sumolang K, Wijonarno A. 2013. Pengamatan Insidental di Taman Nasional Teluk Cenderawasih, Wasior dan WWF-Indonesia Jakarta. [Indonesian]

Tania C. 2014a. Pemantauan dan Studi Hiu Paus di Taman Nasional Teluk Cenderawasih. Laporan Pemantauan dan Studi Tahun 2011-2013, Wasior: WWF-Indonesia, Jakarta. [Indonesian]

Tania C. 2014b. Pemantauan dan Studi Hiu Paus di Taman Nasional Teluk Cenderawasih. Laporan Pemantauan Tahun 2013-2014, Wasior: WWF-Indonesia, Jakarta. [Indonesian]

Tania C. 2015. Pemantauan dan Studi Hiu Paus di Taman Nasional Teluk Cenderawasih. Laporan Pemantauan Tahun 2014-2015 versi 1.1. Balai Taman Nasional Teluk Cenderawasih dan WWF-Indonesia, Jakarta. [Indonesian]

Theberge MM, Dearden P. 2006. Detecting a decline in whale shark Rhincodon typus sightings in the Andaman Sea, Thailand, using ecotourist operator-collected data. Oryx 40 (3): 337-342.

Toha AHA, Widodo N, Subhan B, Himawan R, Tania C, Noor BA, Stewart BS, Madduppa HH. 2016. Close genetic relatedness of whale sharks, Rhincodon typhus in the Indo-Pacific region. AACL Bioflux 9 (3): 458-564

Toha AHA. 2011. Ensiklopedia Biokimia dan Biologi Molekuler. Penerbit EGC, Jakarta. Penerbit EGC, Jakarta. [Indonesian]

Toha AHA. 2014. Studi genetik hiu paus di Taman Nasional Teluk Cenderawasih. Ekspose hasil-hasil kerjasama WWF-UNIPA. 13 Maret 2014. UNIPA, Manokwari. [Indonesian]
Toha, AHA, Ambariyanto, Anwar S, Setiawan JS, Bawole R. 2019. Hiu paus Teluk Cenderawasi. Riset dan monitoring. Penerbit Brainy Bee, Malang.

Toha, AHA, Sumitro SB, Widodo, Hakim L. 2015. Color diversity and distribution of sea urchin Tripneustes gratilla in Cenderawasih Bay Ecoregion of Papua, Indonesia. Egypt J Aquat Res 41: 273-278. DOI: 10.1016/j.ejar.2015.05.001.

Toha, AHA. 2001. Deoxyribonucleic acid. Keanekaragaman, Ekspresi, Rekayasa dan Efek Pemanfaatan. Penerbit Alfabeta, Bandung. [Indonesian]

Vignaud TM, Maynard JA, Leblois R, Meekan MG, VázquezJuárez R, Ramírez-Macías D, Pierce SJ, Rowat D, Berumen ML, Beeravolu C, Baksay S, Planes S. 2014. Genetic structure of populations of whale sharks among ocean basins and evidence for their historic rise and recent decline. Mol Ecol 23 (10): 2590-2601. DOI: $10.1111 / \mathrm{mec} .12754$

Ward RD, Holmes BH, White WT, Last PR. 2008. DNA Barcoding Australian Chondrichthyans: Results and potential uses in conservation. Mar Freshw Res 59: 57-71.

Ward RD, Zemlak TS, Innes BH, Last PR, Hebert PDN. 2005. DNA barcoding Australia's fish species. Phil Trans R Soc London Ser B Biol Sci 360: 1847-1857. DOI: 10.1098/rstb.2005.1716

Wares JP, Cunningham CW. 2001. Phylogeography and historical ecology of the North Atlantic intertidal. Evolution 55 (12): 2455-2469. DOI: 10.1111/j.0014-3820.2001.tb00760.x

Widiastuti N, Boli P, Bato M, Triyanto MA. 2018. Desain prototype destinasi wisata berbasis masyarakat di wilayan TNTC. Research Report. WWF-Indonesia, Jakarta. [Indonesian]

Wong EH, Shivji MS, Hanner RH. 2009. Identifying sharks with DNA barcodes: assessing the utility of a nucleotide diagnostic approach. Mol Ecol Resour 9 (Suppl S1): 243-256. DOI: 10.1111/j.17550998.2009.02653.x. 